\title{
Influence Of Human Resources, Information Technology, Internal Control System And Regional Financial Supervision On Value Of Financial Reporting Information
}

\author{
Muhammad Imran ${ }^{1}$, Nurjannah ${ }^{2}$, Kiki Novita $^{3}$, Abdul Wahid M $^{4}$, Alwahidin $^{5}$ \\ Fakultas Ekonomi dan Bisnis Islam, IAIN Kendari \\ Jl. Sultan Qaimuddin No.17 Kota Kendari Provinsi Sulawesi Tenggara \\ Email : muhimran@iainkendari.ac.id, nurjannah@iainkendari.ac.id, kikinovita@iainkendari.ac.id, \\ wahidmongkito@iainkendari.ac.id, alwahidin@iainkendari.ac.id,
}

\begin{abstract}
ABSTRAK
Penulisan ini bertujuan untuk: (1) menguji dan menganalisis signifikansi pengaruh sumber daya manusia terhadap nilai informasi pelaporan keuangan; (2) Untuk menguji dan menganalisis signifikansi pengaruh teknologi informasi terhadap nilai informasi pelaporan keuangan; (3) Untuk menguji dan menganalisis signifikansi pengaruh sistem pengendalian intern terhadap nilai informasi pelaporan keuangan; (4) Untuk menguji dan menganalisis signifikansi pengaruh pengawasan keuangan daerah terhadap nilai informasi pelaporan keuangan; (5) Untuk menguji dan menganalisis variabel yang lebih dominan berpengaruh terhadap nilai informasi pelaporan keuangan.

Jenis penelitian ini adalah penelitian kuantitatif. Populasi penelitian ini adalah Satuan Kerja Perangkat Daerah di Pemeritah Kota Makassar yang terdiri dari 53 SKPD. Teknik pengambilan sampel menggunakan teknik sampling terhadap kepala bagian keuangan dan bendahara. Metode pengumpulan data dilakukan dengan kuesioner dan diolah dengan menggunakan aplikasi SPSS.
\end{abstract}

Hasil penelitian menunjukkan bahwa (1) sumber daya manusia berpengaruh positif dan signifikan terhadap nilai informasi pelaporan keuangan; (2) teknologi informasi berpengaruh positif dan signifikan terhadap nilai informasi pelaporan keuangan; (3) sistem pengendalian intern berpengaruh positif dan signifikan terhadap nilai informasi pelaporan keuangan; (4) pengawasan keuangan daerah berpengaruh 
positif dan signifikan terhadap nilai informasi pelaporan keuangan; (5) teknologi informasi merupakan variabel yang lebih dominan berpengaruh terhadap nilai informasi pelaporan keuangan.

Kata Kunci :Sumber Daya Manusia, Teknologi Informasi, Sistem Pengendalian Intern, Pengawasan Keuangan Daerah dan Nilai Informasi Pelaporan Keuangan.

\begin{abstract}
MUHAMMAD IMRAN, Dkk. Influence of Human Resources, Information Technology, Internal Control System and Regional Financial Supervision on Value of Financial Reporting Information.

The purposes of the research are: (1) to test and analyze the significant influence of human resources on the value of financial reporting information; (2) To test and analyze the significant effect of information technology on the value of financial reporting information; (3) To test and analyze the significant effect of the internal control system on the value of financial reporting information; (4) To test and analyze the significant effect of local financial oversight on the value of financial reporting information; (5) To test and analyze the more dominant variable affect the value of financial reporting information.
\end{abstract}

The type of this research is quantitative research. The population of this study is the Regional Device Work Unit at Government of Kota Makassar which consists 53 Work Units. The sampling technique uses a sampling technique to the chief financial officer and treasurer. Data collection method was done by questionnaire and processed by using SPSS application.

The results showed that (1) human resources have a positive and significant impact on the value of financial reporting information; (2) information technology has a positive and significant impact on the value of financial reporting information; (3) the internal control system has a positive and significant impact on the value of financial reporting information; (4) the monitoring of regional finances has a positive and significant impact on the value of financial reporting information; (5) information technology is a dominant variable affecting the value of financial reporting information.

Keywords : Human Resources, Information Technology, Internal Control System, Local Financial Supervision and Value of Financial Reporting Information. 


\section{A. PENDAHULUAN}

Fenomena yang terjadi dalam perkembagan sektor publik di Indonesia dewasa ini adalah menguatnya tuntutan akuntabilitas atas lembaga-lembaga publik, baik di pusat maupun daerah. Akuntabilitas dapat diartikan sebagai bentuk kewajiban mempertanggungjawabkan keberhasilan atas kegagalan pelaksanaan misi organisasi dalam mencapai tujuan dan sasaran yang telah ditetapkan sebelumnya, melalui suatu media pertanggungjawaban yang dilaksanakan secara periodik.

Untuk menegakkan akuntabilitas finansial khususnya di daerah, pemerintah daerah bertanggung jawab untuk mempublikasikan laporan keuangan kepada stakeholder. Governmental Accounting Standards Board (1999) dalam Concepts Statement No.1 tentang Objectives of Financial Reporting menyatakan bahwa akuntabilitas merupakan dasar pelaporan keuangan di pemerintahan yang didasari oleh adanya hak masyarakat untuk mengetahui dan menerima penjelasan atas pengumpulan sumber daya dan penggunaannya.

Harus disadari bahwa ada banyak pihak yang akan memanfaatkan informasi dari laporan keuangan yang disajikan oleh pemerintah daerah sebagai dasar pengambilan keputusan sehingga diharapkan laporan tersebut memberikan manfaat bagi para pemakai. Suwardjono (2005) mengatakan bahwa informasi harus bermanfaat bagi para pemakai sama saja dengan mengatakan bahwa informasi harus mempunyai nilai kebermanfaatan (usefulness) merupakan suatu karakteristik yang hanya dapat ditentukan secara kualitatif dalam hubungannya dengan keputusan, pemakai, dan keyakinan pemakai terhadap informasi.

Informasi yang bermanfaat bagi para pemakai adalah informasi yang mempunyai nilai. Informasi akan bermanfaat apabila informasi tersebut dapat mendukung pengambilan keputusan dan dapat dipahami oleh para pemakai. Pemerintah daerah wajib memperhatikan informasi yang disajikan dalam laporan keuangan untuk keperluan perencanaan, pengendalian, dan pengambilan keputusan. Informasi akuntansi yang terdapat di dalam Laporan Keuangan Pemerintah Daerah.

Dari karakteristik kualitatif laporan keuangan pemerintah tersebut, ketepatwaktuan dan keterandalan merupakan dua unsur nilai informasi yang penting terkait dengan pengambilan keputusan berbagai pihak. Ketepatwaktuan merupakan tersedianya informasi bagi pembuat keputusan pada saat dibutuhkan sebelum informasi tersebut kehilangan kekuatan untuk mempengaruhi keputusan. Keterandalan merupakan kemampuan informasi untuk memberi keyakinan bahwa informasi tersebut benar atau valid. Terdapat saling korban (trade-off) antara ketepatwaktuan dan keterandalan/reliabilitas 
untuk mendapatkan kebermanfaatan. Namun, berkurangnya reliabilitas berakibat berkurangnya kebermanfaatan, dimungkinkan untuk mempercepat ketersediaan data secara aproksimasi tanpa mempengaruhi reliabilitas secara material. Dengan begitu ketepatwaktuan dengan aproksimasi justru akan meningkatkan kebermanfaatan secara keseluruhan (Zuliarti, 2012).

Berbicara mengenai pelaporan keuangan dan nilai informasi yang terkandung dalam laporan keuangan pemerintah akan menimbulkan pertanyaan apakah pelaporan keuangan pemerintah selama ini sudah memenuhi kriteria kompetensi informasi yang disyaratkan dalam peraturan perundang-undangan. Apakah laporan keuangan pokok yang terdiri dari Laporan Realisasi Anggaran, Neraca, Laporan Arus Kas, dan Catatan atas Laporan Keuangan (UU No 17 Tahun 2003) telah relevan, andal, dapat dibandingkan, dan dapat dipahami. Banyaknya fenomena laporan keuangan pemerintah yang belum menyajikan data-data yang sesuai dengan peraturan dan masih banyak penyimpangan-penyimpangan yang berhasil ditemukan oleh Badan Pemeriksa Keuangan (BPK) dalam pelaksanaan audit laporan keuangan pemerintah membuat tuntutan masyarakat terhadap penyelenggaraan pemerintahan yang baik (good governance government) meningkat. Hal itu juga yang telah mendorong pemerintah pusat dan pemerintah daerah untuk menerapkan akuntabilitas publik.

Fenomena yang terjadi di Pemerintah Kota Makassar berdasarkan pemeriksaaan laporan keuangan pemerintah daerah pada tahun anggaran 2013 sampai tahun anggaran 2014 memperoleh opini Wajar Dengan Pengecualian (WDP) dan pada tahun 2015 sampai tahun anggaran 2019 memperoleh opini Wajar Tanpa Pengecualian (WTP), ini berarti terjadi peningkatan opini dari tahun 2013 sampai dengan tahun 2019.

Faktor pertama yang mempengaruhi nilai informasi pelaporan keuangan pemerintah daerah adalah kapasitas sumber daya manusia yang melaksanakan sistem akuntansi. Permasalahan penerapan basis akuntansi bukan sekedar masalah teknis akuntansi, yaitu bagaimana mencatat transaksi dan menyajikan laporan keuangan, namun yang lebih penting adalah bagaimana menentukan kebijakan akuntansi (accounting policy), perlakuan akuntansi untuk suatu transaksi (accounting treatment), pilihan akuntansi (accounting choice), dan mendesain atau menganalisis sistem akuntansi yang ada. Kebijakan untuk melakukan aktivitas tersebut tidak dapat dilakukan oleh orang (pegawai) yang tidak memiliki pengetahuan di bidang akuntansi (Desi dan Ertambang, 2008). Sehingga untuk dapat menghasilkan laporan keuangan yang berkualitas, maka kapasitas sumber daya manusia yang melaksanakan sistem akuntansi sangatlah penting.

Faktor kedua yang mempengaruhi nilai informasi pelaporan keuangan pemerintah adalah pemanfaatan teknologi informasi. Seperti kita ketahui bahwa total volume Anggaran Pendapatan dan 
Belanja Negara/Daerah (APBN/D) dari tahun ke tahun menunjukkan peningkatan yang luar biasa. Untuk itu pemerintah pusat dan pemerintah daerah berkewajiban untuk mengembangkan dan memanfaatkan kemajuan teknologi informasi untuk meningkatkan kemampuan mengelola keuangan daerah, dan menyalurkan informasi keuangan daerah kepada pelayanan publik.

Faktor ketiga yang mempengaruhi nilai informasi pelaporan keuangan pemerintah adalah pengendalian intern akuntansi. Sistem akuntansi sebagai sistem informasi merupakan subjek terjadinya kesalahan baik yang disengaja maupun yang tidak disengaja. Oleh karena itu sistem akuntansi memerlukan pengendalian intern atau dengan kata lain sistem akuntansi berkaitan erat dengan pengendalian intern organisasi (Mahmudi, 2007).

Faktor terakhir yang mungkin memiliki pengaruh terhadap nilai informasi pelaporan keuangan pemerintah daerah adalah pengawasan keuangan daerah. Untuk menyajikan informasi keuangan yang handal kepada para pemakai agar sesuai dengan rencana yang ditetapkan, diperlukan media tertentu yang dipandang relevan, yaitu pengawasan keuangan daerah (Tuasikal, 2007). Berdasarkan Peraturan Menteri Dalam Negeri Nomor 51 Tahun 2010 tentang Pedoman Pengawasan Penyelenggaraan Pemerintah Daerah Tahun 2011, yang dimaksud dengan pengawasan adalah proses kegiatan yang ditujukan untuk menjamin agar pemerintahan daerah berjalan secara efektif dan efisien sesuai dengan rencana dan ketentuan peraturan perundang-undangan. Pengawasan terhadap sistem pengendalian internal diarahkan antara lain untuk mendapatkan keyakinan yang wajar terhadap efektivitas dan efisiensi organisasi, keandalan pelaporan keuangan, dan kepatuhan terhadap peraturan perundang-undangan.

Penelitian terdahulu yang dilakukan oleh Desi dan Ertambang (2008) menemukan bahwa pemanfaatan teknologi informasi, dan pengendalian intern akuntansi berpengaruh positif signifikan terhadap keterandalan pelaporan keuangan pemerintah daerah. Kapasitas sumber daya manusia, dan pemanfaatan teknologi informasi berpengaruh positif signifikan terhadap ketepatwaktuan pelaporan keuangan pemerintah daerah. Penelitian ini mengacu pada penelitian sebelumnya yang berkaitan dengan masalah yang akan diteliti: Penelitian Yudianta, dkk (2013) membuktikan secara empiris kapasitas sumber daya manusia, pemanfaatan teknologi informasi, dan pengendalian intern akuntansi berpengaruh positif terhadap kualitas informasi akuntansi pada pelaporan keuangan Satuan Kerja Perangkat Daerah (SKPD) Kabupaten Gianyar. Hal yang perlu ditekankan adalah SKPD Kabupaten Gianyar agar bisa lebih meningkatkan kapasitas SDM yang berkualitas, memaksimalkan pemanfaatan teknologi informasi dan pegendalian intern secara efektif. 
Penelitian lain yang dilakukan oleh Desmiyawati (2014) menyatakan bahwa pengawasan keuangan daerah berpengaruh signifikan positif terhadap nilai informasi pelaporan keuangan. Pengawasan keuangan daerah merupakan salah satu cara untuk membangun dan menjaga legistimasi warga masyarakat terhadap kinerja pemerintah dengan menciptakan suatu sistem pengawasan yang efektif. Sedangkan penelitian Darmayanti dan Domo (2015) yang membuktikan dari hasil pengujian hipotesis, menunjukkan bahwa terdapat pengaruh yang signifikan antara pengawasan keuangan daerah dengan nilai informasi pelaporan keuangan dan hubungannya positif.

Tujuan yang diharapkan dalam penelitian ini adalah untuk mengukur ada atau tidaknya pengaruh dari kompetensi sumber daya manusia, pemanfataan teknologi informasi, sistem pengendalian intern dan pengawasan keuangan daerah terhadap nilai informasi pelaporan keuangan pada Pemerintah Daerah Kota Makassar.

Teori agensi merupakan konsep yang menjelaskan hubungan kontraktual antara prinsipal dan agen. Pihak prinsipal adalah pihak yang memberikan mandat kepada pihak lain, yaitu agen, untuk melakukan semua kegiatan atas nama prinsipal dalam kapasitasnya sebagai pengambil keputusan. Tujuan dari teori agensi adalah pertama, untuk meningkatkan kemampuan individu (baik prinsipal maupun agen) dalam mengevaluasi lingkungan dimana keputusan harus diambil (The belief revision role). Kedua, untuk mengevaluasi hasil dari keputusan yang telah diambil guna mempermudah pengalokasian hasil antara prinsipal dan agen sesuai dengan kontrak kerja (The performance evaluation role).

Teori kegunaan keputusan (decision-usefulness theory), informasi akuntansi akan menjadi referensi dari penyusunan kerangka konseptual Financial Accounting Standard Boards (FABS), yaitu Statement Of Financial Accounting Concepts (SFAC) yang berlaku di Amerika Serikat. Teori ini dikenal dengan nama lain yaitu a theory of accounting to investors. Selain FASB, ada sebuah badan setara dengan FASB yaitu GASB. FAF membuat GASB pada tahun 1984 dalam hubungan "kakak-adik" dengan FASB. GASB bertanggungjawab untuk menetapkan standar akuntansi untuk aktivitas dan transaksi dari pemerintah pusat dan daerah., sedangkan FASB menyusun standar akuntansi untuk semua organisasi lainnya termasuk non pemerintahan dan organisasi non rofit.

Kerangka konseptual dijabarkan dari tinjauan pustaka dan landasan teori berdasarkan penelitian terdahulu, dan dengan mengingat latar belakang penelitian, rumusan masalah maupun tujuan penelitian maka model penelitian dibuat sebagai berikut :

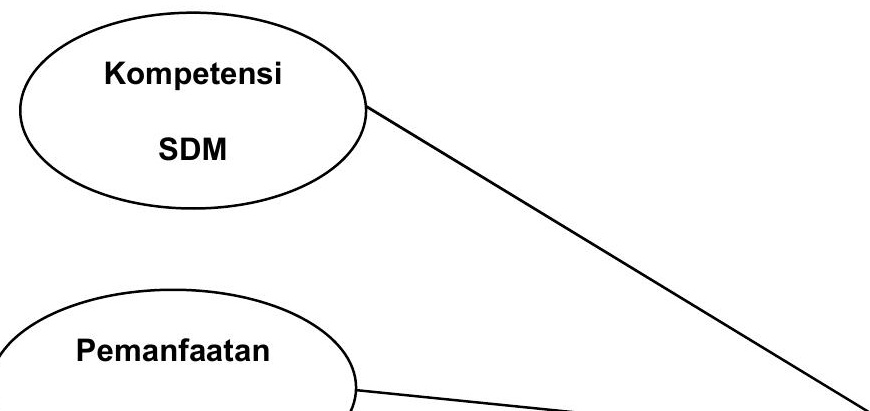




\section{B. METODE PENELITIAN}

Penelitian ini dilakukan di SKPD Pemerintah Kota Makassar. Lokasi ini dipilih atas pertimbangan dapat memberikan informasi yang jelas tentang pengaruh sumber daya manusia, teknologi informasi, sistem pengendalian intern dan pengawasan keuangan daerah terhadap nilai informasi pelaporan keuangan.

Populasi merupakan wilayah generalisasi yang terdiri atas objek atau subjek yang mempunyai kualitas dan karakteristik tertentu yang diterapkan oleh peneliti untuk mempelajari dan kemudian ditarik kesimpulannya. Yang menjadi objek analisis dalam penelitian ini adalah Satuan Kerja Perangkat Daerah sebagai entitas akuntansi. Adapun populasi dalam penelitian ini terdiri dari 53 SKPD.

Metode analisis data yang digunakan dalam penelitian ini adalah regresi linear berganda, yaitu metode analisis untuk lebih dari satu variabel independen. Penelitian ini menggunakan program pengolahan data yaitu SPSS. Dalam penelitian ini, data dianalisis dengan menggunakan alat analisis yang terdiri dari (1) uji instrumen penelitian yang terdiri dari uji validitas dan uji reabilitas; (2) uji asumsi klasik yang terdiri dari uji normalitas, uji multikoleniaritas, dan uji hetereokedastisitas. 


\section{HASIL PENELITIAN DAN PEMBAHASAN}

\section{Hasil Uji F}

Uji simultan digunakan untuk menguji ada tidaknya pengaruh dari variabel bebas secara menyeluruh terhadap variabel terikat dilakukan dengan menggunakan uji $\mathrm{F}$. Uji ini menggunakan $\alpha 5 \%$. Dengan ketentuan, jika signifikansi $<$ dari 0,05 maka hipotesis yang diajukan dapat diterima. Hasil pengujiannya sebagai berikut:

\section{ANOVA $^{\mathrm{a}}$}

\begin{tabular}{|rr|r|r|r|r|r|}
\hline Model & & Sum of Squares & df & Mean Square & F & Sig. \\
\hline & Regression & 1127.860 & 4 & 281.965 & 47.887 & $.000^{\mathrm{b}}$ \\
& Residual & 594.706 & 101 & 5.888 & & \\
& Total & 1722.566 & 105 & & & \\
\hline
\end{tabular}

Tabel diatas menunjukkan bahwa tingkat signifikansi lebih kecil dari 0,05, sehingga dapat dikatakan bahwa sumber daya manusia, teknologi informasi, sistem pengendalian intern dan pengawasan keuangan daerah secara simultan (bersama-sama) mempunyai pengaruh terhadap nilai informasi pelaporan keuangan, dengan probabilitas 0,000. Karena probabilitas jauh lebih kecil dari nilai signifikan 0,05, maka model regresi dapat digunakan untuk memprediksi tingkat nilai informasi pelaporan keuangan.

\section{Hasil Uji Parsial (Uji t)}

Uji parsial digunakan untuk melihat pengaruh masing-masing variabel independen terhadap variabel dependen. Pengujian dilakukan dengan uji t yaitu dengan melihat nilai signifikansi t hitung, Jika nilai signifikansi $<$ dari 0,05 maka dapat dikatakan variabel independen tersebut mempunyai pengaruh terhadap variabel dependen. Hasil pengujiannya adalah sebagai berikut:

\section{Coefficients $^{\mathrm{a}}$}

\begin{tabular}{|c|c|c|c|c|c|}
\hline \multirow[t]{2}{*}{ Model } & \multicolumn{2}{|c|}{ Unstandardized Coefficients } & Standardized & \multirow[t]{2}{*}{$\mathrm{t}$} & \multirow[t]{2}{*}{ Sig. } \\
\hline & $\mathrm{B}$ & Std. Error & Beta & & \\
\hline $1 \quad$ (Constant) & -17.279 & 4.439 & & -3.892 & .000 \\
\hline
\end{tabular}




\begin{tabular}{|l|r|r|r|r|r|}
\hline SumberDayaManusia & .241 & .105 & .215 & 2.295 & .024 \\
PemanfaatanTeknologiInformasi & .671 & .117 & .391 & 5.745 & .000 \\
SistemPengendalianIntern & .389 & .107 & .282 & 3.630 & .000 \\
PengawasanKeuanganDaerah & .336 & .131 & .221 & 2.567 & .012 \\
\hline
\end{tabular}

Berdasarkan tabel di atas, maka persamaan regresi yang terbentuk adalah:

$$
Y=-17,279+0,241 X_{1}+0,671 X_{2}+0,389 X_{3}+0,336 X_{4}
$$

Nilai konstanta adalah -17,279 ini menunjukkan bahwa, jika variabel independen $\left(\mathrm{X}_{1}, \mathrm{X}_{2}, \mathrm{X}_{3}\right.$ dan $\mathrm{X}_{4}$ ) bernilai nol (0), maka nilai variabel dependen $(\mathrm{Y})$ sebesar -17,279.

Koefisien regresi sumber daya manusia $\left(b_{1}\right)$ adalah 0,241 dan bertanda positif. Hal ini berarti, nilai variabel $\mathrm{Y}$ mengalami kenaikan sebesar 0,241 yang disebabkan peningkatan nilai variabel $\mathrm{X}_{1}$, dan apabila variabel independen lainnya bernilai tetap.

Koefisien bertanda positif menunjukkan adanya hubungan yang searah antara variabel sdm $\mathrm{X}_{1}$ dengan variabel $\mathrm{Y}$. Semakin baik kualitas sumber daya manusia, maka nilai informasi pelapooran keuangan akan semakin meningkat.

Koefisien regresi teknologi informasi $\left(b_{2}\right)$ adalah 0,671 dan bertanda positif. Hal ini berarti, nilai variabel $\mathrm{Y}$ mengalami kenaikan sebesar 0,671 yang disebabkan peningkatan nilai variabel $\mathrm{X}_{2}$, dan apabila variabel independen lainnya bernilai tetap.

Koefisien bertanda positif menunjukkan adanya hubungan yang searah antara variabel $\mathrm{X}_{2}$ dengan variabel Y. Semakin tinggi teknologi informasi maka nilai informasi pelaporan keuangan akan semakin meningkat.

Koefisien regresi sistem pengendalian intern $\left(b_{3}\right)$ adalah 0,389 dan bertanda positif. Hal ini berarti, nilai variabel Y mengalami kenaikan sebesar 0,389 yang disebabkan peningkatan nilai variabel $\mathrm{X}_{3}$, dan apabila variabel independen lainnya bernilai tetap.

Koefisien bertanda positif menunjukkan adanya hubungan yang searah antara $X_{3}$ dengan variabel Y. Semakin tinggi sistem pengendalian intern, maka akan membuat nilai informasi pelaporan keuangan akan semakin meningkat.

Koefisien regresi pengawasan keuangan daerah $\left(\mathrm{b}_{4}\right)$ adalah 0,336 dan bertanda positif. Hal ini berarti, nilai variabel Y mengalami kenaikan sebesar 0,336 yang disebabkan peningkatan nilai variabel $\mathrm{X}_{4}$, dan apabila variabel independen lainnya bernilai tetap. 
Koefisien bertanda positif menunjukkan adanya hubungan yang searah antara $X_{4}$ dengan variabel Y. Semakin tinggi pengawasan keuangan daerah, maka akan membuat nilai informasi pelaporan keuangan akan semakin meningkat.

Melalui statistik uji-t yang terdiri dari Sumber Daya Manusia $\left(\mathrm{X}_{1}\right)$, Teknologi Informasi $\left(\mathrm{X}_{2}\right)$, Sistem Pengendalian Intern $\left(\mathrm{X}_{3}\right)$ dan Pengawasan Keuangan daerah $\left(\mathrm{X}_{4}\right)$ dapat diketahui secara parsial pengaruhnya terhadap Nilai Informasi Pelaporan Keuangan (Y).

\section{Uji R $\mathbf{R}^{2}$ (Koefisien Determinasi)}

Uji koefisien determinasi bertujuan untuk mengetahui seberapa besar kemampuan variabel dependen dapat dijelaskan oleh variabel independen. Hasil uji koefisien determinasi $\left(\mathrm{R}^{2}\right)$ dapat dilihat pada tabel berikut:

Model Summary

\begin{tabular}{|l|r|r|r|r|}
\hline Model & $\mathrm{R}$ & R Square & $\begin{array}{c}\text { Adjusted R } \\
\text { Square }\end{array}$ & $\begin{array}{c}\text { Std. Error of the } \\
\text { Estimate }\end{array}$ \\
\hline 1 & $.809^{\mathrm{a}}$ & .655 & .641 & 2.42656 \\
\hline
\end{tabular}

a. Predictors: (Constant), PengawasanKeuanganDaerah,

PemanfaatanTeknologiInformasi, SistemPengendalianIntern,

SumberDayaManusia

b. Dependent Variable: NilaiInformasiPelaporanKeuangan

Dari tabel di atas terdapat angka $\mathrm{R}$ sebesar 0,809 yang menunjukkan bahwa hubungan antara nilai informasi pelaporan keuangan dengan keempat variabel independennya cukup kuat, karena berada di defenisi sangat kuat yang angkanya 0,5. Sedangkan nilai $\mathrm{R}$ square sebesar 0,655 atau 65,5\% ini menunjukkan bahwa variabel nilai informasi pelaporan keuangan dapat dijelaskan oleh variabel karakteristik sumber daya manusia, teknologi informasi, sistem pengendalian intern dan pengawasan keuangan daerah sebesar 65,5\% sedangkan sisanya 34,5\% dapat dijelaskan dengan variabel lain yang tidak terdapat pada penelitian ini.

\section{Pembahasan}


Hasil pengujian menunjukan bahwa variabel sumber daya manusia berpengaruh positif dan signifikan terhadap nilai informasi pelaporan keuangan pada SKPD di Pemerintah Kota Makassar. Hal ini berarti bahwa terdapat hubungan yang searah antara Sumber Daya Manusia dengan nilai informasi pelaporan keuangan dalam arti jika kompetensi sumber daya manusianya berkualitas maka nilai informasi pelaporan keuangan juga akan membaik sesuai harapan.

Hasil pengujian menunjukkan bahwa variabel teknologi informasi berpengaruh positif dan signifikan terhadap nilai informasi pelaporan keuangan. Hal ini berarti bahwa terdapat hubungan yang searah antara teknologi informasi dengan nilai informasi pelaporan keuangan dalam arti apabila teknologi informasi yang digunakan dalam pengelolaan laporan keuangan memiliki penguasaan secara baik maka nilai informasi pelaporan keuangan juga akan baik.

Hasil pengujian statistik menunjukkan bahwa SPI berpengaruh positif dan signifikan terhadap nilai informasi pelaporan keuangan. Hal tersebut mengandung arti bahwa semakin tinggi SPI, maka kualitas nilai informasi pelaporan keuangan akan semakin baik.

Hasil pengujian menunjukkan bahwa variabel pengawasan keuangan daerah berpengaruh positif dan signifikan terhadap nilai informasi pelaporan keuangan. Hal ini berarti bahwa terdapat hubungan yang searah antara pengawasan keuangan daerah dengan nilai informasi pelaporan keuangan dalam arti apabila pengawasan keuangan daerah yang di memiliki tiap SKPD baik maka nilai informasi pelaporan keuangan juga akan baik.

\section{SIMPULAN DAN SARAN}

\section{Simpulan}

1. Sumber daya manusia berpengaruh positif dan signifikan terhadap nilai informasi pelaporan keuangan pada SKPD di Pemerintah Kota Makassar. Semakin berkualitas sumber daya manusia maka nilai informasi pelaporan keuangan akan semakin baik pula.

2. Teknologi informasi berpengaruh positif dan signifikan terhadap nilai informasi pelaporan keuangan pada SKPD di Pemerintah Kota Makassar. Semakin baik pemanfaatan dari teknologi informasi yang digunakan maka nilai informasi pelaporan keuangan akan semakin baik pula. 
3. Sistem pengendalian intern berpengaruh positif dan signifikan terhadap nilai informasi pelaporan keuangan pada SKPD di Pemerintah Kota Makassar. Penerapan sistem pengendalian intern yang cukup baik pada karyawan akan mendorong para karyawan untuk bekerja dengan lebih baik dan ke arah pekerjaan-pekerjaan yang lebih produktif. Dengan kata lain, peningkatan sistem pengendalian intern yang cukup baik pada karyawan dapat meningkatkan nilai informasi pelaporan keuangan.

4. Pegawasan keuangan daerah berpengaruh positif dan signifikan terhadap nilai informasi pelaporan keuangan pada SKPD di Pemerintah Kota Makassar. Pengawasan keuangan daerah yang baik pada SKPD akan mencegah penyalagunaaan dana yang tidak semestinya. Dengan kata lain, peningkatan pengawasan keuangan daerah yang baik dapat meningkatkan kualitas nilai informasi pelaporan keuangan.

\section{Saran}

1. Bagi SKPD di Pemerintah Kota Makassar diharapkan dapat memperhatikan kualitas sumber daya manusia yang berkompeten serta memiliki basic dibidang masing-masing sehingga diharapkan lebih mampu menghasilkan dan meningkatkan nilai informasi pelaporan keuangan pada SKPD di Pemerintah Kota Makassar.

2. Bagi SKPD di Pemerintah Kota Makassar disarankan agar membentuk suatu sistem teknologi informasi yang dapat menunjang peningkatan nilai informasi pelaporan keuangan, seperti sistem jaringan yang dapat menghubungkan komputer yang satu dengan komputer yang lain dengan tujuan untuk mempermudah proses transfer data pengelolaan keuangan. 
3. Bagi SKPD Pemerintah Kota Makassar disarankan dapat meningkatkan efektifitas pengendalian intern seperti kepala dinas (Kadis) memeriksa catatan akuntasi baik keuangan maupun program agar terbentuk tatanan laporan yang baik dari semisal salah entri dan menyajikan laporan keuangan.

4. Bagi peneliti selanjutnya disarankan untuk menguji variabel-variabel lainnya yang berpengaruh terhadap nilai informasi pelaporan keuangan seperti sistem akuntansi keuangan daerah, pemahaman SAP, komitmen organisasi dan variabel-variabel pendukung lainnya.

5. Bagi peneliti selanjutnya disarankan agar menambah jumlah sample, memperluas untuk analisis serta menambahkan indikator - indikator yang lebih relevan sehingga diperoleh hasil penelitian yang lebih akurat dan berkualitas.

\section{DAFTAR PUSTAKA}

Arfianti, Dita. 2011. Analisis Faktor-Faktor Yang Mempengaruhi Nilai Informasi Pelaporan Keuangan Pemerintah Daerah (Studi pada Satuan Kerja Perangkat Daerah di Kabupaten Batang). Program Sarjana UNDIP. Semarang.

Cohen, L., et al. 2007. Research Methods in Education. (Sixth edition). New York: Routledge. 
Dhany, Apriansyah. 2010. Pengaruh kapasitas sumber daya manusia, pemanfaatan teknologi informasi, dan pengendalian internal akuntansi terhadap nilai informasi pelaporan keuangan pemerintah (studi empiris pada satuan kerja perangkat daerah kota Bengkulu).

Delano, Galuh Fajar dan Deviani. 2013. Pengaruh Kapasitas SDM, Pemanfaatan Teknologi Informasi dan Pengawasan keuangan Terhadap Nilai Informasi Pelaporan Keuangan Pemerintah Daerah.

Dedi Rianto Rahardi.2007. Peranan Teknologi Informasi dalam Peningkatan Pelayanan Sektor Publik. Seminar Nasional teknologi 2007.

Desmiyawati. 2014. Faktor- Faktor Yang Mempengaruhi Keandalan dan KetepatanWaktu Pelaporan Keuangan (Study Empiris Pada SKPD Pemda Riau). Jurnal Akuntansi FEUniversitas RIAU, Vol. 2, No. 2, (ISSN 2337-4314).

Domo dan Darmayanti. 2015. Pengaruh Kapasitas Sumber Daya Manusia. Pengendalian Intern dan Pengawasan Keuangan Terhadap Keterandalan dan Ketepatwaktuan Pelaporan Keuangan (Studi Empiris Pada SKPD Pemerintah Kota Malang).

Eman. 2006. Teknologi Informasi, Chapter 2 Digital Collection. Universitas Kristen Petra: Surabaya.

Fitriyani, Riska. 2014. Pengaruh Penggunaan Teknologi Informasi, Keahlian Pemakai dan Intensitas Pemakaian Terhadap Kualitas Informasi Akuntansi. Universitas Bengkulu.

Ghozali, Imam. 2011. Aplikasi Analisis Multivariate dengan Program SPSS, Edisi Kelima. Badan Penerbit Universitas Diponegoro: Semarang.

Haag, Stephen and Keen. 1996. Information Technology: Tomorrow's Advantage Today. Hammond: McGraw-Hill College.

Halim, Abdul. 2001. Akuntansi Keuangan Daerah. Salemba Empat : Jakarta.

Hamzah, Ardi. 2009, Evaluasi Kesesuaian Model Keperilakuan dalam penggunaan Teknologi Informasi di Indonesia., Universitas Trunojoyo.

Harken, Dharma. 2014. Pengaruh Penerapan Sistem Akuntansi Keuangan Daerah Terhadap Kualitas Informasi Laporan Keuangan Dengan Sistem Pengendalian Intern Sebagai Variabel Intervening. (Studi Empiris Pada SKPD Kota Solok).

Hevesi, G. Alan. 2005. Standards for Intenal Control in New York State Government. www.osc.state.ny.us

Indriantoro, Nur dan Bambang Supomo. 2002. Metode Penelitian Bisnis Untuk Akuntansi Manajemen, Edisi Pertama. BPFE: Yogyakarta. 
Indriasari, Desi dan Ertambang Nahartyo. 2008. "Pengaruh Kapasitas Sumber Daya Manusia, Pemanfaatan Teknologi Informasi, Dan Pengendalian Intern Akuntansi Terhadap Nilai Informasi Pelaporan Keuangan Pemerintah Daerah”. SNA 11 Pontianak.

Lucas, Henri. 2000. Information Technology for Management, Edisi Ketujuh. Irwin/McGrawHill.

Mahmudi. 2007. Manajemen Kinerja Sektor Publik. Edisi 3. (UPP STIM YKPN, Yogyakarta).

Martin. 2002. Managing Information Technology.

Mardiasmo. 2006. Akuntansi Sektor Publik. Yogyakarta: Penerbit Andi.

Matindas, Rudolf Wennemar. 2002. Manajemen Sumber Daya Manusia, Lewat Konsep Ambisi, Kenyataan dan Usaha. Jakarta: Edisi II, Grafiti.

Mawhinney, Charles H. and Albert Lederer. 1990. A Study of Personal Computer Utilization by Managers, Informaation \& Management, May: 243-253.

Nuwasdzarrin. 10 Oktober 2014. Pemanfaatan Teknologi Informasi dalam Bidang Akuntansi. (http://nuwasdarrin.student.unej.ac.id/?p=12).

Nurillah, AS Syifa. Dan Muid Dul. 2014. Pengaruh Kompetensi Sumber Daya Manusia, Penerapan Sistem Akuntansi Keuangan Daerah, Pemanfaatan Teknologi Informasi, Dan Sistem Pengendalian Intern Terhadap Kualitas Laporan Keuangan Pemerintah Daerah (Studi Empiris Pada SKPD Kota Depok).

Oxford English Dictionery (OED). 1995. (Sumber : www.oed.com)

Peraturan Menteri Dalam Negeri Nomor 13 Tahun 2006 Tentang Pedoman Pengelolaan Keuangan Daerah.

Peraturan Pemerintah Nomor 105 Tahun 2000 dan Kepmendagri Nomor 29 Tahun 2002

Peraturan Pemerintah Nomor 60 Tahun 2008 Tentang Sistem Pengendalian Intern Pemerintah. 
Peraturan Pemerintah Nomor 24 Tahun 2005 tentang Standar Akuntansi Pemerintah.

Peraturan Pemerintah Nomor 71 Tahun 2010 tentang Standar Akuntansi Pemerintah.

Peraturan Pemerintah Nomor 60 Tahun 2008 tentang Sistem Pengendalian Intern Pemerintah.

Peraturan Pemerintah, 2005. Standar Akuntansi Pemerintahan. PP nomor 24 Tahun 2005.

Peraturan Pemerintah Nomor 56 Tahun 2005 tentang Sistem Informasi Keuangan Daerah.

Peraturan Pemerintah Nomor 58 Tahun 2005 tentang Pengelolaan Keuangan Daerah.

Rosalina, Faristina. 2011. Faktor-Faktor Yanga Mempengaruhi Keandalan dan Timeliness Pelaporan Keuangan Badan Layanan Umum (Studi pada BLU di Kota Semarang).

Roviyanti, Devi. 2009. Pengaruh Kompetensi Sumber Daya Manusia dan Penerapan Sistem Akuntansi Keuangan Daerah Terhadap Kualitas Laporan Keuangan Daerah (Survei Pada Organisasi Daerah (OPD) Kabupaten Tasikmalaya.

Setiawati, Erma dan Shinta Permata Sari. 2014. Kualitas Pelaporan Keuangan Pemerintah Daerah Ditinjau Dari Sumber Daya Manusia, Pengendalian Intern, Pemanfaatan Teknologi Informasi Dan Pemahaman Akuntansi (Studi Empiris Pada Pemerintah Kabupaten dan Kota di Wilayah Eks Karesidenan Surakarta).

Simamora, Henry. 1995. Manajemen Sumber Daya Manusia. STIE YPKN: Yogyakarta.

Sutarman. 2012. Pengantar Teknologi Informasi. Bumi Aksara: Jakarta.

Suwardjono. 2005. Teori Akuntansi Perekayasaan Pelaporan Keuangan. Yogyakarta: BPFE.

Syarifudin, Akhmad. 2014. Pengaruh Kompetensi Sumber Daya Manusia Dan Peran Audit Internal Terhadap Kualitas Laporan Keuangan Pemerintah Daerah Dengan Variabel Intervening Sistem Pengendalian Internal Pemerintah ( Studi Empiris Pada Pemkab Kebumen). 
Thompson, Ronald L., Christoper A. Haggings, and Jane M. Howell. 1991. Personal Computing: Toward a Conceptual Model of Utilization, Mis Quarterly, pp. 125-143.

Tuasikal, Askam, 2007, Pengaruh Pemahaman Sistem Akuntansi dan Pengelolaan Keuangan Daerah terhadap Kinerja Satuan Kerja Perangkat Daerah. Jurnal Akuntansi dan Keuangan Sektor Publik, Vol.08, No.01, Februari 2007.

Undang-Undang Nomor 17 Tahun 2003 tentang Keuangan Negara.

Undang-Undang Nomor 33 Tahun 2004 tentang Perimbangan Keuangan antara Pemerintah Pusat dan Pemerintah Daerah.

Undang-Undang Nomor 32 Tahun 2004 tentang Pemerintah Daerah.

William and Sawyer. 2007. Using Information Technology. Penerbit Andi: Yogyakarta.

Wilkinson, 2000. Sistem Informasi dan Informasi, Edisi Kedua. Terjemahan oleh Marianus Sinaga. Erlangga: Jakarta.

Yosa. 2010. Pengawasan Keuangan. Diunduh dari www.itjen-depdagri.go.id

Yudianta, I Gede Agus. Ni Made Adi Erawati. 2013. Pengaruh Sumber Daya Manusia, Teknologi Informasi Dan Pengendalian Intern Terhadap Kualitas Laporan Keuangan. Jurnal Ekonomi. Universitas Udayana.

Zuliarti. 2012. Pengaruh Kapasitas Sumber Daya Manusia, Pemanfaatan Teknologi Informasi, Dan Pengendalian Intern Akuntansi Terhadap Nilai Informasi Pelaporan Keuangan Pemerinta Daerah (Studi Pada Pemerintah Kabupaten Kudus). Universitas Muria Kudus. 